\title{
FROM THE HISTORY OF CONFERENCES ON THE MACHINE AND MECHANISM SCIENCE
}

\author{
J. WOJNAROWSKI \\ State Higher Vocational School in Nowy Sącz \\ 33-300 Nowy Sącz, ul. Staszica 1, POLAND \\ E-mail: jwojnarowski@pwsz-ns.edu.pl
}

\begin{abstract}
In the course of the past sixty years of the Polish Committee for the Theory of Machines and Mechanisms (PC TMM) 24 scientific and didactic conferences have been held. The subject matter of these conferences, generally organized every other year, comprised problems of the classification, analysis and synthesis of mechanisms, the dynamics of machine systems, investigations concerning self-excited vibrations, the stability of the systems, the control of machines and biomechanics. The numbers of submitted papers as well as the number of participants substantiate the need of organizing such conferences, their importance and the activity of the Polish Committee of TMM for the purpose of creating a platform for the presentation and discussion of new research methods in the domain of mechanisms, machines, biomechanics and mechatronics.
\end{abstract}

Key words: Scientific Conferences on TMM, Congresses of IFToMM, $15^{\text {th }}$ World Congress in 2019.

\section{Introduction}

The $25^{\text {th }}$ Conference on the Theory of Machines and Mechanisms falls on the $60^{\text {th }}$ anniversary of the establishment of the Polish Committee for the Theory of Machines and Mechanisms (PC TMM), and also coincides with the $60^{\text {th }}$ anniversary of the first conference on the Theory of Machines and Mechanisms. This double anniversary is a good opportunity to recall the history of held conferences closely related to promote research and development in the field of Theory of Machines and Mechanisms involving issues of structural analysis and synthesis, kinematics and dynamics of mechanisms and machines, and research in developing new methods for measuring the size of the dynamic of enlargement to automatic control issues.

Sixty years of the Polish Committee for the Theory of Machines and Mechanisms, a significant period of development of the science of mechanisms and machines, given that the Polish Committee for the Theory of Machines and Mechanisms co-sponsored the foundation of the International Federation for the Promotion of Mechanism and Machine Science (IFToMM) in Zakopane in 1969 and as an affiliated member of the IFToMM became a regular participant in the World Congress of the Federation in 2019 to organize 15 IFToMM World Congress in Cracow and Zakopane at the $50^{\text {th }}$ anniversary of its founding. The $25^{\text {th }}$ Conference on the Theory of Machines and Mechanisms is a good opportunity to remind the short history of previously held conferences, the development of the science of mechanisms and machines.

\section{Scientific Conferences on Mechanism and Machine Science}

The $1^{\text {st }}$ Scientific and Didactic Conference was held on $15^{\text {th }}-23^{\text {rd }}$ June, 1956. The meeting was organized in Rogów, sponsored by the Chair of the Theory of Machines and Mechanisms, and is considered to have been the $1^{\text {st }}$ Scientific and Didactic Conference. It was devoted to didactic, programme and scientific problems concerning the Theory of Mechanisms and Machines.

\section{Prof. Jan Oderfeld was elected President of the Polish Committee of TMM.}


The $2^{\text {nd }}$ Scientific Conference on TMM was organized by the Academy of Mining and Metallurgy in Cracow. It was held from $23^{\text {rd }}$ to $27^{\text {th }}$ November 1957. At this conference papers from 11 Polish academic technical schools were presented.

The $3^{\text {rd }}$ Scientific Conference on TMM was organized by the Chair of the Theory of Machines and Mechanisms at the Technical University of Warsaw. It was held on $8^{\text {th }}-16^{\text {th }}$ July 1961 and gathered 80 participants, 32 of whom presented their papers. Among the participants there were also the heads of Chairs of Machine Elements from Universities of Technology.

The $4^{\text {th }}$ Scientific Conference on TMM was organized also at the Technical University of Warsaw, in Zegrzynek. It was held on September $26^{\text {th }}-28^{\text {th }}, 1963$ with the participation of 50 persons, including scientists from abroad dealing with the theory of machines and mechanisms. Twenty four papers were presented at this conference.

The $5^{\text {th }}$ Scientific Conference on TMM was organized by the Chair of the Theory of Mechanisms and Machines at the Technical University of Łódź. The conference took place in Łódź on $28^{\text {th }} \mathrm{June}-1^{\text {st }} \mathrm{July}$ 1965. The number of the participants amounted to 82 , including 13 foreigners. 86 papers were presented on the research work carried out both in Poland and abroad.

At this conference Prof. Oderfeld wished its participants on behalf of the Rector of the Technical University of Warsaw successful proceedings. Prof. Parszewski delivered a lecture on "Trends of research in the domain of TMM in Poland in the years 1963-1965". Among the guests from abroad there were Prof. G. Boestad from Stockholm, M. Konstantinov from Sofia and R. Bogdan from Bucarest. The latter delivered a lecture on "The influence of changing the gear ratio on the characteristics of an articulated pentagon", presenting this topic clearly from the scientific point of view. Prof. Zdzislaw Parszewski was the Chairman of the organizing committee.

The $6^{\text {th }}$ Scientific and Didactic Conference on TMM was held in Świeradów Zdrój on $15^{\text {th }}-17^{\text {th }}$ September 1975. It was organized by the Institute of Design and Machine Operation at the Technical University of Wrocław. 48 authors, including 10 foreigners, submitted their papers. The participants represented all technical universities in Poland. The conference material was published in the proceedings of the Institute of Design and Machine Operation in 1975. This conference was organized 10 years after the $5^{\text {th }}$ conference organized in Łódź. Dr. Stefan Miller was the Chairman of the organizing committee.

The $7^{\text {th }}$ Scientific and Didactic Conference on TMM was held on $15^{\text {th }}-18^{\text {th }}$ December, 1977 and was organized by the Academy of Agriculture in Lublin together the Polish Committee of TMM in Kazimierz on the Vistula. The number of participants amounted to 125.

Dr Zdzislawa Rotter was the Chairman of the organizing committee.

The $8^{\text {th }}$ Scientific Conference on TMM was held in May 1980 at Kozubnik, sponsored by the Academy of Mining and Metallurgy together with the Polish Committee of TMM. Six plenary and 56 session papers were presented. Prof. Karol Tomaszewski was the Chairman of the organizing committee.

The $9^{\text {th }}$ All-Polish Scientific and Didactic Conference on TMM took place in Cracow on the $2^{\text {nd }}$ and $3^{\text {rd }}$ December 1982. Prof. A. Morecki and Jan Oderfeld presented the "Actual State of Investigations and Teaching of the Theory of Machines and Mechanisms". This conference preceded the $6^{\text {th }}$ International Congress on TMM in New Delhi, which was held on $15^{\text {th }}-20^{\text {th }}$ December 1983.

The $10^{\text {th }}$ Scientific and Didactic Conference on TMM was held in Warsaw on $3^{\text {rd }}$ to $5^{\text {th }}$ December 1984. The conference materials comprised a set of 51 papers, published in the Scientific Fascicles of the Technical University of Warsaw (362 pages). The Chairman of the Organizing Committee was Prof. Adam Morecki.

The $11^{\text {th }}$ Scientific and Didactic Conference on TMM was held in Zakopane in April $27^{\text {th }}-30^{\text {th }}$, 1987, organized by the Institute of Mechanics and Machine Design of the Silesian Technical University 
together with the Polish Committee of TMM. Eighty eight papers were published in two issues of the Scientific Fascicle of the Technical University of Silesia, viz. Mechanics No. 85 and also in the fascicle of the Institute of Mechanics and Machine Design. Besides the conference materials a fascicle was issued containing abstracts in English. Prof. Józef Wojnarowski was the Chairman of the Organizing Committee.

The $12^{\text {th }}$ Scientific and Didactic Conference on TMM was held in Bielsko-Biała from $22^{\text {nd }}$ to $24^{\text {th }}$ November 1989, organized by the branch of the Institute of Mechanical Design at the Technical University of Łódź. 33 papers were published in the "Conference Proceedings" (463 pages). Prof. Marek Trombski was the Chairman of the Organizing Committee.

The $13^{\text {th }}$ Scientific and Didactic Conference on TMM took place in Koszalin and Mielno on $19^{\text {th }}$ $21^{\text {st }}$ September, 1992. Fifty three papers were submitted, 36 of which were presented. The number of authors amounted to 82. There were also participants from Ukraine (Lvov, Kiew and Vinnica, 10 papers), Belarus (Monilev) and Egypt. 88 papers were submitted and published in the Scientific Fascicles of the Academy of Engineering in Koszalin (328 pages). Before the conference the abstracts had been published as one volume in English (136 pages). Dr Jerzy Milanowski was the Chairman of the Organizing Committee. At the time of the Conference Prof. Adam Morecki was elected President of the Polish Committee of TMM.

The $14^{\text {th }}$ Scientific and Didactic Conference on TMM was organized by the Institute of FluidFlow Machines of the Polish Academy of Sciences on $23^{\text {rd }}-26^{\text {th }}$ November, 1994 in Gdynia - Gdańsk. Seventy five papers were published in the Scientific Fascicles of the Institute of Fluid-Flow Machines at the Polish Academy of Sciences (507 pages). Prof. Wiesław Ostachowicz was the Chairman of the Organizing Committee.

The $15^{\text {th }}$ Scientific and Didactic Conference on TMM was organized by the Faculty of Mechanical Engineering at the Technical University of Białystok on $17^{\text {th }}-21^{\text {st }}$ September, 1996 at Białowieża. Seventy five papers were submitted, published by the Wydawnictwo Politechniki Białostockiej (Publishers of the Technical University of Białystok). The number of participants amounted to 76, representing 26 Polish research centers and 4 from abroad (Belarus, Bulgaria, Switzerland and Ukraine). Dr. Franciszek Siemieniako was the Chairman of the Organizing Committee.

The $16^{\text {th }}$ Scientific and Didactic Conference on TMM was held in Rzeszów - Jaworze on $22^{\text {nd }}-$ $25^{\text {th }}$ September, 1998, organized by the Chair of Technical Mechanics at the Faculty of Mechanical Engineering and Aviation, Technical University of Rzeszów. Eighty one papers had been submitted, 17 of which were presented as posters. The proceedings were published in two volumes: vol. 1: 344 pages, vol. 2 339 pages. Dr. Wiesław Żylski was the Chairman of the Organizing Committee.

The $17^{\text {th }}$ Scientific and Didactic Conference on TMM was held on $6^{\text {th }}-8^{\text {th }}$ September, 2000 at Jachranka near Warsaw. It was organized by the Institute of Aviation and Applied Mechanics in cooperation with the Polish Committee of TMM. Seventy one papers were presented and published in the "Proceedings of the Scientific and Didactic Conference on the Theory of Machines and Mechanisms", edited by A. Morecki, K. Kędzior and C. Rzymkowski (510 pages), it ought to be mentioned that 68 pages contained a treatise on the "Theory of Machines and Mechanisms in Poland in the years 1938-2000", the authors of which are A. Morecki, K. Kędzior and C. Rzymkowski. Prof. Krzysztof Kędzior was the Chairman of the Organizing Committee.

The $18^{\text {th }}$ Scientific and Didactic Conference on TMM was held in Lądek Zdrój on $18^{\text {th }}-20^{\text {th }}$ September, 2002. The participants, whose number amounted to 96, presented their papers in five plenary sessions and two poster sessions - 63 papers, all of which were reviewed and published as Scientific Investigations of the Institute of Design and Machine Operation, Technical University of Wrocław, No, 85, series Conferences No. 25 (ISSN 0324-9646). The conference was organized by the Institute of Design and Machine Operation, Technical University of Wrocław, in cooperation with the Polish Committee of TMM. 
Prof. Antoni Gronowicz was the Chairman of the Organizing Committee.

At the time of the Conference Prof. Józef Wojnarowski was elected Chairman of the Polish Committee of TMM.

The $19^{\text {th }}$ Didactic Conference on TMM was organized in Cracow on $12^{\text {th }}-16^{\text {th }}$ September, 2004. This conference was organized under the auspices of His Magnificence Rector, Prof. Ryszard Tadeusiewicz, Chair of Robotics and Dynamics of Machines, Academy of Mining and Metallurgy in Cracow with the Committee of TMM. The papers were published in two volumes, vol. 1 containing 43 papers (324 pages) and vol.2 38 papers (293 pages). The problem paper devoted to the design of machine and mechatronic systems, entitled "Human Scale Intelligent Systems" was delivered by Prof. Delbert Tesar from the University of Texas in Austin. Prof. Tadeusz Uhl was the Chairman of the Organizing Committee.

The $20^{\text {th }}$ Scientific and Didactic Conference on TMM was held on $18^{\text {th }}-19^{\text {th }} 2006$ in Zielona Góra, organized by the Faculty of Mechanical Engineering at the University of Zielona Góra in cooperation with the Polish Committee of TMM. Prof. Mirosław Galicki was the Chairman of the Organizing Committee.

The $21^{\text {st }}$ Conference on TMM was organized in Szczyrk by theUniversity of Bielsko-Biała on $22^{\text {nd }}$ $-25^{\text {th }}$ September, 2008. Ninety one papers were submitted but only 52 papers published in conference proceedings. Prof. Iwona Adamiec-Wójcik was the Chairman of the Organizing Committee.

The $22^{\text {nd }}$ Scientific Conference on TMM was organized by the Technical University of Białystok on 27 - 30 June, 2010 in Augustów in cooperation with the Polish Committee of TMM. Seventy five papers were submitted. Prof. Franciszek Siemieniako was the Chairman of the Organizing Committee.

The $23^{\text {rd }}$ International Scientific Conference on TMM\&UM was organized in Kołobrzeg on $19^{\text {th }}-22^{\text {nd }}$ September, 2012. It was organized by the Mechanical Department of the Koszalin University of Technology. Sixty one papers were submitted, including 9 written by authors from abroad. The Conference articles were published in the quarterlies: Acta Mechanica et Automatica in Polish and the Journal of Applied Mechanics and Engineering in English. Prof. Tadeusz Bill was the Chairman of the Organizing Committee.

The $24^{\text {th }}$ International Scientific Conference on TMM\&UM was held in Szklarska Poręba on $21^{\text {th }}-24^{\text {th }}$ September, 2014. It was organized by the Institute of Design and Machine Operation, Wroclaw University of Technology. Sixty nine papers were submitted.

Among the guests invited, who submitted plenary papers were: the former President of IFToMM, Marco Ceccarelli (Italy) and Member of the Executive Council of IFToMM, Prof. Burghard Corves (Germany), Prof. Erwin Lovasz from Romania and Prof. Z. Iskakow (Kazachstan). The following review articles were submitted:

- M. Ceccarelli (Italy) "What can be innovation in MMS: achievements and community developments"

- B. Corves (Aachen RFN)"A novel flexible and versatile robotic concept with optimized grasping process and reconfiguration"

- E. - C. Lovasz et al.( Romania): "Novel solution for leg motion with 5-link belt mechanism"

- J. Wojnarowski: "Influence of Copernicus idea on the development of mechanisms of machines"

- Z. Iskakow (Kazachstan): The nonlinear vibration of orthogonal mechanism of shaking table"

Prof. Antoni Gronowicz was the Chairman of the Organizing Committee.

The Conference papers were published in the International Journal Applied Mechanics and Engineering, University Press Zielona Góra. Vol.19, No.3 in 2014 and Abstracts in Modern Trends in Theory of Machines and Mechatronic Systems, Wroclaw Sept. 2014 pp.134.

The conference was a great success of the Polish Committee of TMM that was emphasized by M. Ceccarelli the former President of IFToMM at the Plenary Meeting of the PC TMM which took place at the $24^{\text {th }}$ International Conference on the Theory of Machines and Mechatronic Systems (TMiUM). 


\section{Concluding remarks}

The evolutive basis of science with constantly changing technical means determines the methodological criteria of progress in science and technology, involving the style of thinking in research and design of mechanisms and machines. Basing on investigations carried out so far, old theories are included in new ones, thanks to which idealized models and new paradigms become interchanged. Therefore, the National Committees, and thus also the Polish Committee of TMM develop an adequate feedback, leading to an evolution of the theory, the models of mechanisms, machines and processes, the design of prototypes, as well as modern means of investigations and new methods of calculation.

The establishment of the International Federation for the Promotion of Mechanism and Machine Science (IFToMM) and active contribution of Polish scientists in its establishment and activities was of much importance and it permitted, in spite of numerous restrictions, to make an international cooperation in the domain of mechanisms and machines.

A significant landmark of IFToMM is its World Congress on the theory of machines and mechanisms organized every four years. To date, fourteen IFToMM World Congresses have taken place in the following cities all over the world: Varna, Bulgaria (1965); Zakopane, Poland (1969); Kupari, Yugoslavia (1971); Newcastle- upon-Tyne, United Kingdom(1975); Montreal, Canada (1979); New Delhi, India (1983); Seville, Spain (1987); Prague, Czech Republic (1991); Milano, Italy (1995); Oulu, Finland (1999); Tianjin, China (2004); Besancon, France (2007); Guanajuato, Mexico (2011); Taipei, Taiwan (2015). The $15^{\text {th }}$ Congress of IFToMM will take place at the end of June and begonning of July, 2019 in Cracow - Zakopane. Currently the 47 National Committees are affiliated to IFToMM.

The Polish contribution to the world-wide development of the theory of mechanisms and machines has always been appreciated. At present, our representatives more and more frequently take part in the activities of the Commissions and Committees and also in the Congresses of IFToMM.

On the occasion of the $40^{\text {th }}$ anniversary of the foundation of IFToMM, Prof. Marco Ceccarelli in agreement with the Chair of IFToMM, Poland, Prof. J. Wojnarowski, to commemorate this anniversary, installed a plaque. The plaque was unveiled during the $23^{\text {th }}$ Conference on Problems Concerning the Development of Machines in Zakopane on $26^{\text {th }}-28^{\text {th }}$ January, 2010.

In order to commemorate the $50^{\text {th }}$ anniversary of the existence of the Polish Committee of TMM a book under the title "Fifty Years of the Polish Committee of TMM, 1956-2006", (188 pages), containing also biographies of the members of the Committee, has been published.

Moreover, the author of this historical outline prepared a paper to the first book of a series that is focused on Mechanism and Machine Science (MMS) entitled: The Significance and Role of IFToMM Poland in the Creative Development of Mechanism and Machine Science, pp.367-382, [in M. Ceccarelli (ed.). Technology Developments: the Role of Mechanism and Machine Science and IFToMM, Mechanism and Machine Science 1, Springer Science 2011].

Following the development and operation of the Polish Committee for the Theory of Machines and Mechanisms (PC TMM) it is easy to see that the very active participation of Polish scientists in the formation and activities of the IFToMM Federation has been significant for the development of engineering machinery.

- Polish contribution to the world mechanism and machine science has been appreciated, which was manifested among other things in appointing our representatives to prominent positions, in particular Prof. Adam Morecki who was for two terms the Secretary General and in the years 1992-1995 he was President of the Federation.

- Prof. Jan Oderfeld was an honorary member of IFToMM, and Prof. Krzysztof Kędzior was for the past two terms a member of the Executive Committee IFToMM , Prof. Teresa Zielinska on $13^{\text {th }}$ Congress in Juanjuato, Mexico, was elected General Secretary for the terms 2012-15 and again in Taipei for the 2016-2019 term of the Executive Council. Many members of PC TMM work in the Technical Committees of the IFToMM. 


\section{4. $15^{\text {th }}$ World Congress in 2019 in Cracow - Zakopane}

The application of $15^{\text {th }}$ World Congress in 2019 was submitted by Prof. Józef Wojnarowski, chair of IFToMM Poland but the information about the form, the venue and the planned budget of the $15^{\text {th }}$ World Congress in Cracow was presented by Prof. Tadeusz Uhl. On October 29, 2015 at the General Assembly of the $14^{\text {th }}$ World Congress in Taipei which awarded the PC TMM organization of this Congress in Cracow - Zakopane.

Prof. M. Ceccarelli, president of IFToMM, presented me as a Fouding Father of IFToMM and congratulated to Polish Committee (Fig.1). Turning to President Caccarelli, the General Assembly and all participants $14^{\text {th }}$ World Congress, Prof. J. Wojnarowski said (Fig.2): "On behalf of the Polish IFToMM Committee and myself, I cordially invite all Participants as well as all IFToMM COMMUNITIES to Poland and more specifically to Cracow and Zakopane to celebrate the $50^{\text {th }}$ anniversary of the founding of IFToMM in Zakopane in 1969. See you all in 2019 in Cracow, old nice City, City of Nicolaus Copernicus - creator of the heliocentric system of the World!'”.

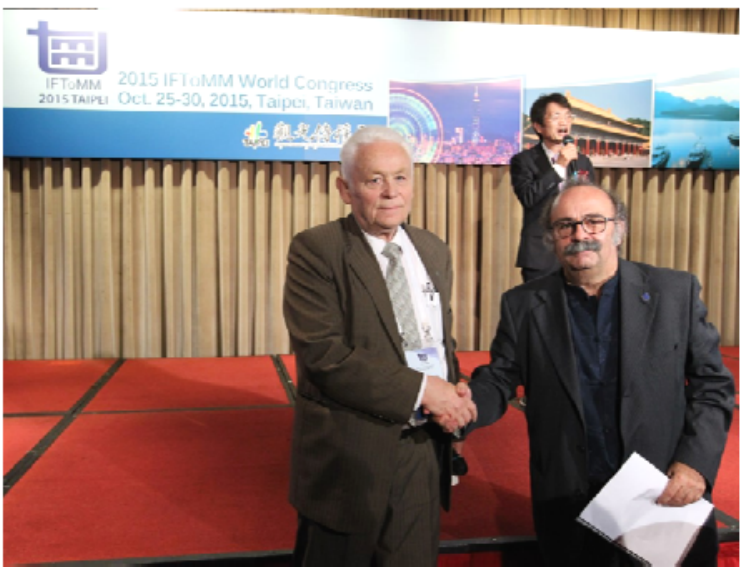

Fig 1. Congratulation to Prof. J. Wojnarowski from the President of IFToMM - Prof. M. Caccarelli

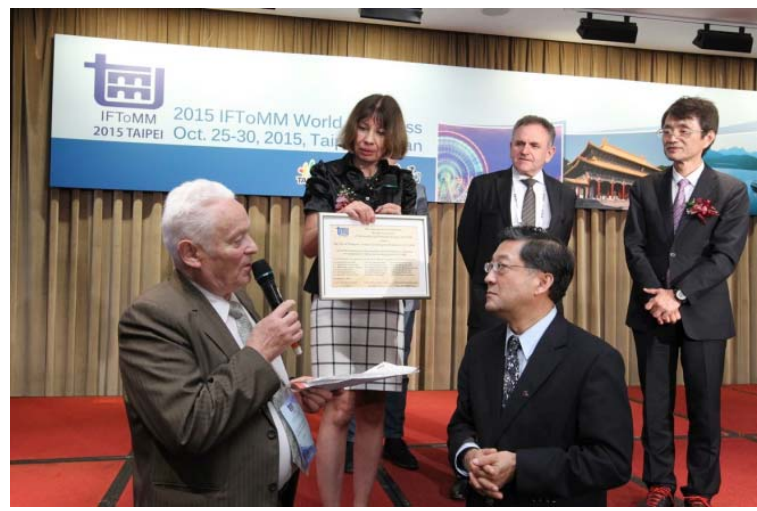

Fig. 3. Prof.: T. Zielińska, T. Uhl, Y. Nakamura, J. Wojarowski, Shuo Hung Chang (General Chair)

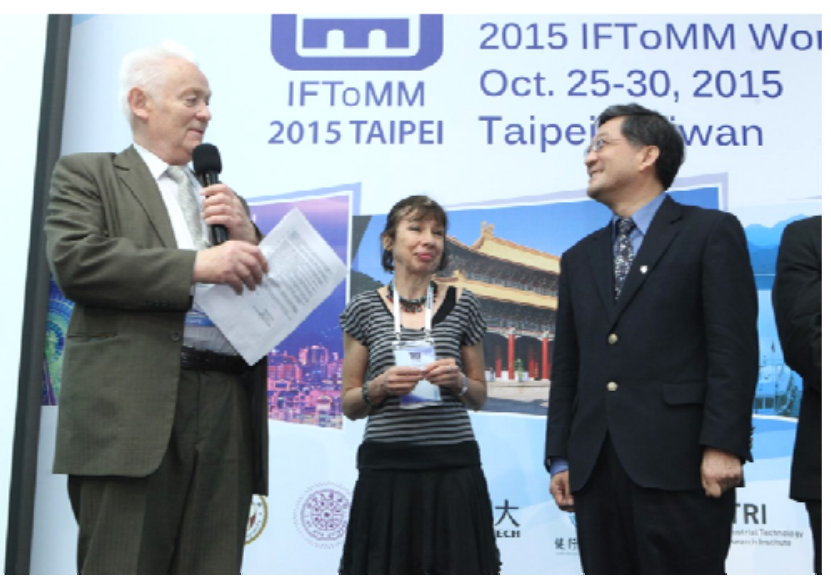

Fig. 2. Prof.: J. Wojnarowski, T. Zielińska, Shuo Hung Chang - inviting for $15^{\text {th }}$ World Congress in 2019 in Cracow

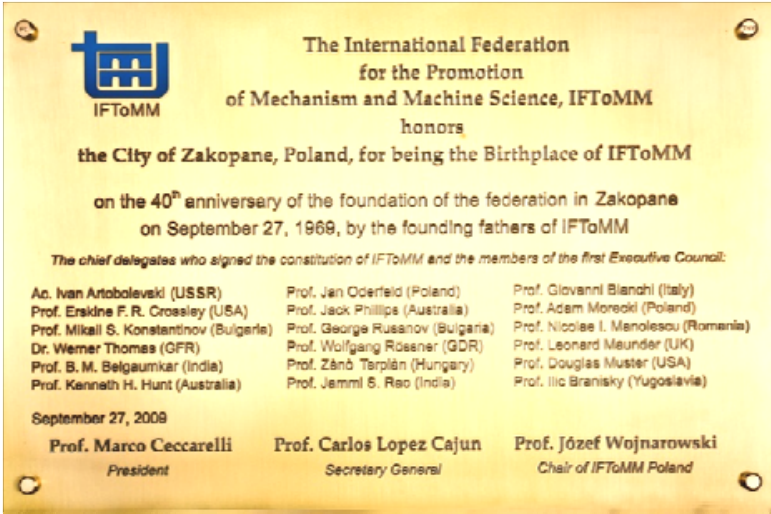

Fig. 4. Photo of the plaque unveiling from the occasion of the 40th anniversary of establishing IFToMM in Zakopane in 1969 
Prof. Shuo Hung Chang (Fig.3), gived thanks for the recived from Polish Committee copy of plaque (Fig.4). He said: "I herby take this opportunity to express my sincere appreciation to your kind support; without your attendance, this conference would not be such a great one! I would therefore like to reiterate my thanks to your significant contribution and truly hope to see you o the next quadrenial IFToMM World Congress to be held in Poland on 2019!".

The year 2012 for the Polish Committee was significant because from January 1, developing its activities it must act in the new formula in the term of 2012 - 2016. Now the Polish Committee is composed of members who were elected to the Committee in Mechanical Engineering at the Polish Academy of Sciences.

At the Internet site http://www.tmm.ath.bielsko.pl you can check the activities of the Polish Committee of TMM. While compact information about the authors can be found in the conference programme at: http://it.pwsz-ns.edu.pl/tmm2016/.

I would like to express my gratitude to all the members of the Polish Committee for their creative development of the discipline of the theory mechanisms and machines and for their participation in the proceedings of the IFToMM and the Polish Committee of TMM.

\section{Honourable and dear participants of the conference TMMiUM Rytro'2016}

We owe the success of the conference to the number of Participants, the Honorary Patronage of Prof. Mariusz Cygnar the Rector of the University of Technology and fruitful cooperation of members of the Honorary, Scientific and Organizing Committees.

I am grateful to the Authors of articles for preparing their manuscripts on time and to PT Reviewers for their effort to review the articles presented at the $25^{\text {th }}$ Conferences TMMiUM RYTRO'2016. I would like to express warms thanks to Prof. E. Walicki - Editor-in Chief for the professional assistance of the staff of the International Journal of Applied Mechanics and Engineering.

TI would like to thank all the Participants for their willingness to participate in the debates and work of the Polish Committee for the Theory Machines and Mechanisms. Last but not least, I wish to express my thanks to the Polish Academy of Sciences for supporting our endeavours.

On behalf of the Polish Committee for the Theory Machine and Mechanisms and myself I would like to express my warm wishes to all future participants. I hope they will have a successful pleasant stay and meeting, creative debates in the field of Mechanism and Machine Science, pleasant meetings in Rytro summer resort and mountain rambling centre, located in the Sacz Beskid Mountains on the Poprad river and at the foot of Prehyb peak of the mountain $(1175 \mathrm{~m})$ in the Radziejowa Range.

Welcome to Rytro, Poland, venue of the $25^{\text {th }}$ Conferences TMMiUM September 18 - 21, 2016.

\section{References}

[1] Wojnarowski J. (2006): 50 $0^{\text {th }}$ Anniversary of the Polish Committee for the Theory of Machines and Mechanisms. Warszawa - Gliwice.

[2] Wojnarowski J. (2009/2010): PC TMM on the 40 ${ }^{\text {th }}$ Anniversary of the Foundation of IFToMM. - GliwiceWarszawa-Zakopane.

[3] Wojnarowski J. (2011): The Significance and Role of IFToMM Poland in the Creative Development of Mechanism and Machine Science, pp.367-382, [in M. Ceccarelli (ed.). Technology Developments: the Role of Mechanism and Machine Science and IFToMM, Mechanism and Machine Science 1, Springer Science].

[4] Wojnarowski J. (2015): Report on the 14th IFToMM 2015 World Congress which was held on October 25-30, 2015 Journal IJAME Vol. 20, pp. I-VI. 